\title{
Standpunt
}

\section{Die bydrae van technikons in hoër onderwys}

\begin{abstract}
Wanneer 'n mens hoër onderwys dwarsoor die wêreld in oënskou neem, kom twee bree eienskappe sterk na vore. Die eerste cen is taamlik positief: hoër onderwys is steeds sterk in aanvraag en word met ekonomiese en persoonlike ontwikkeling verbind. Die meeste regerings glo dat dit arbeidsproduktiwiteit verhoog en tot hoër langtermyn ekonomiese groei lei, en dat dit die geval is omdat gegradueerdes oor die waardes en vermoëns beskik wat deur ekonomieë benodig word wat al hoe meer tegnologie- en kennisgerig is. Gevolglik geniet gegradueerdes langer en beter besoldigde indiensneming as diegene sonder technikon- of universiteitsopleiding. In 'n kennisgedrewe en kennisalhanklike wêreld het bemarkbare kennis en vaardighede 'n voorvereiste vir sinvolle indiensneming geword.
\end{abstract}

Die beskikbaarheid van menslike hulpbronne is selfs nog belangriker in die nuwe konteks van ' $n$ wêreldekonomie. Dit is omdat dit soveel belangriker geword het om hulpbronne te hê wat dit aantreklik maak vir buitelandse investering en internasionale produksie. Menslike hulpbronne is een belangrike faktor, infrastruktuur en wet en orde is ander faktore. Globalisering beloon lande wat oor die menslike hulpbronne beskik wat 'n moderne ekonomie kan ondersteun en mededingbaarheid kan verhoog. Suid-Afrika is 'n mededinger in ' $n$ wêreldmark wat deur sterk mededinging, vinnig bewegende produkte en ongelooflike innovering gekenmerk word. Ons beloning en sukses lê in die vaardighede, kennis en kwaliteit van ons menslike hulpbronne.

Die tweede faktor is egter meer onrusbarend. Die onderwyssektor skyn dwarsoor die wêreld in 'n krisis te wees. In amper alle lande maak hoër onderwys op grootskaalse regeringsbefondsing staat en, in 'n era van wydverspreide fiskale beperkinge, sukkel sowel nywerheids- as ontwikkelende lande met die uitdaging om die gehalte van hoër onderwys te bewaar of te verbeter, terwyl onderwysbegrotings, veral uitgawes per student, saamgepers word. Een antwoord hierop is dat regerings groter institusionele spesialisering en groter privaat befondsing wil stimuleer. In Suid-Afrika het die befondsingsvlak (dic sogenaamde a-waarde) van 1986 tot 1997 gedaal. Vir 1998 staan die syfer op ongeveer $65 \%$. In 1955-randwaarde het die staatsubsidie per student van R707 in 1987 tot R481 in 1998 gedaal. Hierdie feit, tesame met die onvermoë van baie studente om hul klasgelde te betaal, plaas 'n groot las op die hoëronderwyssektor om hul diens en standaarde te handhaaf.

Entrepreneursdenke, nuwe bestuursbenaderings, nuwe opleidingsalliansies, samewerkingsooreenkomste en veral ook meer koste-effektiewe en doeltreffende opleidingsmetodes sal op die pad van die suksesvolle technikon en universiteit lê.

\section{TEGNOLOGIEONDERRIG AAN TECHNIKONS}

Die tegnologiese en ekonomiese ontwikkeling van ' $n$ land het 'n groot effek op die uitset van 'n land se hoëronderwysstelsel en ook anders om.

Die ekonomie van Suid-Afrika staan binne 'n snelle oorgang vanaf die Industriële Era na die Inligtings- en Tegnologie-era en dit impliseer dramatiese veranderinge binne die hoëronderwysstelsel van ons land. Van die grootste veranderinge is die vervanging van hiërargiese organisatoriese strukture deur "netwerkstrukture", en outokratiese leierskap met besielende deelnemende leierskap en bestuur. Lokale markte word vervang deur internasionale markte waar innovasie, spanwerk en tyd oorlewings- en suksesfaktore is. Kwaliteit word op internasionale vlak gedefinieer en daar is volgehoue investering in toepaslike tegnologiese navorsing en ontwjkkeling. Snelle tegnologiese ontwikkeling bring ook mec dat groot getalle mense wat tans in die arbeidsmark verkeer na technikons gaan stroom vir heropleiding of aanleer en verwerwing van nuwe vaardighede en kennis. Waar dic technikons aanvanklik binne die Industriële Era grootliks gekonsentreer het op "tegniese" opleiding wat 'n hoë vaardigheidsvlak en relatief lae akademiese ondersteuningsvlak gehad het, het die Inligtingsera radikalc aanpassings gebring. Die rekenaar, outomatisasie en internasionale standaarde het feitlik elke beroepsgebied binnegedring en het 'n tweeledige elfek gehad - die totstandkoming van 'n groot verskeidenheid nuwe tegnologiegebaseerde bcroepe en die radikale verhoging van die teoretiese en kundigheidsvereistes van ' $n$ beroep (met gepaardgaande afname in handvaardigheidsvereistes). Beroepspesialisasie, of eerder gespesialiseerde opleiding vir duidelik gedefinieerde beroepsvelde ondersteun deur die nodige navorsing en ontwikkeling, is ' $n$ kenmerk van die Inligtings- en Tegnologie-era. 'n Goed georganiseerde en doeltreffende kliënte-nasorgdiens (studenteheropleidingsdiens) het ook ' $n$ vereiste geword.

Die respck wat daar oor honderde jare wêreldwyd vir geleerdes ("men of learning") was, is binne 'n relatief kort periode vervang deur respek vir kundige en, meer spesifiek, beroepskundige mense. Die algemene kundige wat iets van alles af weet en op 'n hoé akademiese vlak ondernemende gesprekke kan voer en argumente kon aanvoer, raak al hoe minder in aanvraag. Die aanvraag is nou toenemend na tegnologies kundige persone met gespesialiseerde kennis en vaardighede. Aspekte soos beroepsetiek, entrepreneursdenke, multikulturele samewerking, kommunikatiewe vermoëns, ensovoorts vorm nou 'n integrale deel van die werkgewer se verwagtinge van 'n gegradueerde.

Die technikons het nog altyd die onderrig en oordrag van tegnologie en die lewering van beroepspesialiste aan die arbeidsmarkte van Suid-Afrika as hulle kerntaak gesien.

Binne technikonverband word tegnologie-oordrag geassosieer met navorsing oor en identifikasie en oordrag van die jongste en toepaslikste kundigheid in die vorm van kennis, prosesse, metodieke en vaardighede binne 'n bepaalde beroepsveld, met die doel om die sosiale en ekonomiese welvaart van die land te bevorder.

Dit impliseer 'n direkte betrokkenheid van technikons by die skepping, oordrag en evaluering van kennis, kundigheid en tegnologic deur navorsing, onderrig en nasionale en internasionale skakeling. Dit impliseer ook 'n direkte en aktiewe betrokkenheid by die wêreld van werk. Dit impliseer ook die relevansie van leerplanne vir die wêreld van werk.

\section{VOORKEURE VAN WERKGEWERS IN DIE TOEKOMS}

Die daarstelling van 'n geïntegreerde unitêre hoëronderwysstelsel in Suid-Afrika, die toekenning van grade deur die technikons tot op doktorale vlak, die inbeweeg van talle oorsese hoëronderwysinrigtings na die Suid-Afrikaanse mark en die potensiecl "gelykmakende" rol van SAQA (South African Qual- 
ity Association) gaan veroorsaak dat gegradueerdes nie langer 'n klein elitc groepie bly nie.

Die vraag wat ontstaan is: Hoc gaan werkgewers in dic toekoms bepaal wic hulle wil aanstel, en gaan daar duidelike voorkeure wees sover dit gegradueerdes betref?

Die Association of Graduate Recruiters (AGR) het onlangs in Amerika hierdie probleem ondersoek en tot dic gevolgtrekking gekom dat daar in die tockoms basies twee tipes gegraducerdes gaan wees om in diens te neem. Eerstens, die beroepspesialiste binne sekerc duidelik omskrewe werksareas, soos ingenicurswese, geneeskunde, inligtingstegnologie, tekstielontwerp, joernalistiek, keramiektegnologie en -ontwerp, produksiebestuur, regte, voedseltegnologie, ensovoorts, waar 'n goeie tegnologiese onderbou en gespesialiseerde beroepskennis ' $n$ vereiste is. (Na gelang die wêreld dieper in die Tegnologiese Era inbeweeg, gaan daar 'n sterk groei in beroepe en indiensneming binne hierdie groep wees.)

Tweedens sal daar gesoek word na die veelsydige gelecrdes ("generalists") waar vakkeuses van mindele belang is en waar afgeronde, denkende kandidate eerder oorweeg word. Vaardighede wat die hoogste aangeslaan word, is interpersoonlike vaardighede, die vermoë om in 'n span te werk, aanpasbaarheid en kommunikatiewe vermoëns.

Dit wil voorkom asof die akademiese reputasie van ' $n$ spesifieke universiteit en technikon tog ook 'n rol speel ten opsigte van voorkeur vir sekere gegradueerdes en die kandidate wat van inrigtings met ' $n$ reputasic van akademiese of tegnologiese uitnemendheid en min studente-onrus kom. Ek is van mening dat hierdie voorkeurfaktor in die toekoms in SuidAfrika gaan toeneem.

\section{TEGNOLOGIEONTWIKKELING IN SUID-AFRIKA}

Omdat die technikons so nou by tegnologie-oordrag en beroepsonderwys betrokke is, is in 1996 ' $n$ navorsingsprojek aan Technikon Pretoria geloods met die primêre doel om 'n omvattende ondersoek te doen na die faktore wat die instelling, ontwikkeling en oordrag van tegnologie in Suid-Afrika aanhelp. Dic vraelys is ontwikkel vir uitvoerende amptenare in die privaat sektor en by regeringsondersteunde laboratoriums en instellings, vir senior regeringsamptenare van departemente wat met hierdie studievelde gemoeid is, en vir uitvoerende amptenare en tegnologiegebaseerde lede van fakulteite aan hoëronderwysinstellings. Die vraelyste is an 237 uitvoerende amptenare gestuur en altesame 118 antwoorde is teruggekry. Respondente moes die volgende aandui:

_ Die belangrikheid van 'n bepaalde faktor vir die instelling $\mathrm{en}$ ontwikkeling van tegnologie in ' $n$ land; en

_ die mate waarin daardie besondere faktor ingestel/gebruik word (die rol wat dit speel) om die instelling en ontwikkeling van tegnologie in Suid-Afrika te versterk.

Die breëkategorie-faktore wat die instelling van tegnologic bepaal, is deur die respondente soos in tabel I aangeslaan. Uit tabel 1 blyk dit dat die beskikbaarheid van hoogs geleerde en geskoolde menslike hulpbronne as een van die belangrikste voorvereistes vir die instelling en ontwikkeling van tegnologie in 'n land beskou word.

Drie van die eerste vier breë kategorieë het op menslike hulpbronne betrekking, dit wil sê, 'n relatief groot bron van

TABEL 1 Aanslag van faktore wat die instelling van tegnologie bepaal

\begin{tabular}{|c|c|c|c|c|}
\hline \multirow{2}{*}{ BREËKATEGORIE-FAKTORE } & \multicolumn{2}{|c|}{ BELANGRIKHEID } & \multicolumn{2}{|c|}{ ROL GESPEEL } \\
\hline & $\begin{array}{l}\text { Frekwensie- } \\
\text { persentasie }\end{array}$ & $\begin{array}{l}\text { Aanslag- } \\
\text { posisie }\end{array}$ & $\begin{array}{l}\text { Frekwensie- } \\
\text { persentasie }\end{array}$ & $\begin{array}{l}\text { Aanslag- } \\
\text { posisle }\end{array}$ \\
\hline 1. Die beskikbaarheid van waagkapitaal/risikokapitaal & 79,0 & 6 & 39,0 & 9 \\
\hline $\begin{array}{l}\text { 2. 'n Relatief groot bron van uiters hoogs geskoolde } \\
\text { menslike hulpbronne }\end{array}$ & 88,8 & 1 & 42,4 & 7 \\
\hline $\begin{array}{l}\text { 3. Die teenwoordigheid van entrepreneurs wat die eise } \\
\text { van riskante beleggings verstaan. }\end{array}$ & 84,3 & 3 & 42,2 & 8 \\
\hline $\begin{array}{l}\text { 4. Die betaan van akademiese instellings } \\
\text { (universiteite en technikons) wat vir die uitmuntend- } \\
\text { heid van hulle akademiese programme en toege- } \\
\text { paste navorsing bekend is. }\end{array}$ & 84,3 & 3 & 51,5 & 4 \\
\hline $\begin{array}{l}\text { 5. Die rol van die regering of regeringsagentskappe } \\
\text { (militêr, NASA, WNNR, SNO, ens.). }\end{array}$ & 72,2 & 9 & 52,8 & 2 \\
\hline 6. Markfaktore, d.w.s. besondere markbehoeftes. & 81,8 & 5 & 54,2 & 3 \\
\hline $\begin{array}{l}\text { 7. Die infrastruktuur van die land (vervoer, telekom- } \\
\text { munikasie, ens.) }\end{array}$ & 78,0 & 7 & 61,2 & 1 \\
\hline $\begin{array}{l}\text { 8. Die bestaan van 'n groot basis wetenskaplike kennis } \\
\text { en uitvindings. }\end{array}$ & 77,1 & 8 & 44,7 & 5 \\
\hline 9. Die mate waarin tegnologie-oordrag kan plaasvind. & 85,8 & 2 & 43,4 & 6 \\
\hline
\end{tabular}


TABEL 2 Gedetailleerde faktore wat die hoogste aangeslaan word in terme van ontwikkeling van tegnologie

\begin{tabular}{|c|c|c|}
\hline GEDETAILLEERDE FAKTOR & BELANGRIKHEID & ROL GESPEEL \\
\hline 1. Politieke bestendigheid in 'n land & $90,9 \%$ & $35,6 \%$ \\
\hline $\begin{array}{l}\text { 2. Onderwys en opieiding van mense, d.w.s. ontwikkeling van hoëvlak } \\
\text { menslike hulpbronne deur die subsidiëring van technikons en } \\
\text { universiteite }\end{array}$ & $90,7 \%$ & $49,8 \%$ \\
\hline $\begin{array}{l}\text { 3. Die rol van akademiese instellings by die verskaffing van hoëvlak } \\
\text { menslike hulpbronne }\end{array}$ & $90,5 \%$ & $52,8 \%$ \\
\hline $\begin{array}{l}\text { 4. Die beskikbaarheid van hoëvlak tegnologies geskoolde menslike } \\
\text { hulpbronne in 'n organisasie }\end{array}$ & $89,0 \%$ & $43,0 \%$ \\
\hline 5. 'n Bobestuur wat tegnologiese ontwikkeling ondersteun & $88,3 \%$ & $39,8 \%$ \\
\hline $\begin{array}{l}\text { 6. Die bestaan van 'n tegnologiestrategie/ heropbou- en ontwikkeling- } \\
\text { strategie }\end{array}$ & $88,3 \%$ & $39,6 \%$ \\
\hline $\begin{array}{l}\text { 7. Die nodigheid om rendement en prosesse by vervaardiging te } \\
\text { verbeter }\end{array}$ & $88,3 \%$ & $44,3 \%$ \\
\hline $\begin{array}{l}\text { 8. Die vermoë van die bobestuur om nuwe tegnologieë te verstaan en } \\
\text { sy steun vir tegnologieontwikkeling }\end{array}$ & $87,9 \%$ & $43,9 \%$ \\
\hline $\begin{array}{l}\text { 9. Die fondse in 'n begroting wat vir tegnologieontwikkeling of heropbou } \\
\text { en ontwikkeling opsy gesit is }\end{array}$ & $86,2 \%$ & $40,7 \%$ \\
\hline $\begin{array}{l}\text { 10. Die mate waarin ' } n \text { organisasie bereid en in staat is om nuwe } \\
\text { tegnologie te bekom }\end{array}$ & $86,0 \%$ & $46,0 \%$ \\
\hline 11. Die mate waarin tegnologieoordrag kan plaasvind & $85,8 \%$ & $43,4 \%$ \\
\hline
\end{tabular}

hoogs geskoolde menslike hulpbronne (1), die teenwoordigheid van entrepreneurs wat die eise van riskante beleggings verstaan (3), en die bestaan van akademiese instellings wat vir die uitmuntendheid van hulle akademiese programme en toegepaste navorsing bekend is (4).

Dit blyk uit die opname dat Suid-Afrika se prestasie op hierdie gebied as baie swak aangeslaan word, aangesien respondente die rol wat hierdie drie breë kategorieë speel, onderskeidelik sewende, agste en vierde (uit nege breë kategorieë), met 'n gemiddelde prestasiepunt van 45,3 persent, geplaas het.

Elf gedetailleerde faktore wat die hoogste aangeslaan word in terme van belangrikheid vir die ontwikkeling van tegnologie in Suid-Afrika word in tabel 2 aangedui.

Vyf uit die tien topfaktore het betrekking op menslike hulpbronne, naamlik die beskikbaarheid van hoëvlak tegnologies geskoolde menslike hulpbronne $(2: 90,7 \% ; 3: 90,5 \% ; 4: 89,0 \%)$, en op die bobestuur se ondersteuning vir $(5: 88,3 \%)$ en vermoë om tegnologiese ontwikkeling te verstaan $(8: 87,9 \%)$.

'n Vlugtige blik op hierdie opnameresultate toon duidelik dat die beskikbaarheid van hoëvlak menslike hulpbronne wat tegnologies hoogs geskoold is, as een van die belangrikste voorvereistes vir sinvolle bydraes tot tegnologiese innovasie in ' $n$ land beskou word. Dit, tesame met die beklemtoning van die rol van hoëronderwysinstellings, dui daarop dat Suid-Afrika maar swak presteer. Dit is dus van die allergrootste belang dat hoëronderwysinstellings hulle posisie moet hersien in die lig van hulle rol by die ontwikkeling van geskikte hoëvlak tegnologies geskoolde menslike hulpbronne en hul verhoogde bydrae tot die ontwikkeling en instelling van tegnologie.

Die Tegnologiese Era bring reuse veranderings en as SuidAfrika wil presteer, sal ons hoèronderwysinstellings meer en beter tegnologiesgeskoolde mense moet lewer. Die technikons het 'n beduidende rol te speel om 'n nuwe generasie produkte aan die arbeidsmark te lewer ten einde ons mededingend, produktiwiteit en vermoë tot tegnologiese innovasie beduidend te beïnvloed. Die vraag wat pla is of hulle die visie, vermoë en akademiese wilskrag het om dit te doen.

\section{D.J.J. VAN RENSBURG TECHNIKON PRETORIA}

